\title{
海洋環境におけるコンクリート構造物中の 塩化物イオンの固定化性状に及ぼす中性化の影響
}

\author{
武田 均 $1 \cdot$ 大脇英司 $2 \cdot$ 丸屋 剛 3 \\ 1正会員 大成建設株式会社 技術センター土木技術研究所 \\ （干245-0051 神奈川県横浜市戸塚区名瀬町344-1） \\ E-mail:hitoshi.takeda@sakura.taisei.co.jp \\ 2 正会員 大成建設株式会社 技術センター土木技術研究所 \\ （干245-0051 神奈川県横浜市戸塚区名瀬町 344-1） \\ 2 正会員 大成建設株式会社 技術センター土木技術研究所 \\ （干245-0051 神奈川県横浜市戸塚区名瀬町 344-1）
}

\begin{abstract}
海洋環境にある構造物を対象として, コンクリート中に浸入した塩化物イオンの固定化性状について検 討した。コンクリート中において自由塩化物イオンと固定塩化物イオンが吸着平衡関係にあると仮定した 場合に，ある自由塩化物イオン濃度をしきい值として，低濃度側と高濃度側では異なる吸着平衡関係にあ ると考えられた。 また，中性化したコンクリート中では，吸着平衡関係が変化することによって固定され る塩化物イオン量が低下寸ると考えられた。本論文は，これらの吸着平衡に関して，構造物の調査データ に基づいて検討したものである.
\end{abstract}

Key Words : concrete, chloride ion, binding, carbonation, adsorption equilibrium

\section{1.はじめに}

近年，構造物の耐久性向上に関する社会的な関心が高 まる中，新設構造物の設計や既設構造物の補修対策の設 計においても, 種々の劣化機構に対寸る耐久性の照查が 行われている1). なかでも, 塩害による鉄筋腐食は代 表的な劣化機構であり, 合理的な設計のために, 構造物 が曝される様々な環境作用に対応可能な，塩害に対する 耐久性能の照查技術が求められている. このような背景 のもと，本論文は複合劣化や乾湿環境を考慮した鉄筋腐 食の発生時期や腐食の進行を予測するために必要な情報 であるコンクリート中における塩化物イオンの存在状態 について検討したものである.

コンクリートに浸入した塩化物イオンは, 細孔溶液中 に溶解あるいはセメント水和物に吸着または固定された 状態で存在すると考えられており，コンクリート中の塩 化物イオンの固定化性状に関寸る研究 2) 1 5) もいくつ かある. しかし，構造物における実験結果の検証や構造 物のコンクリート中の塩化物イオンの存在状態に関する 報告は少ない 16，17)。コンクリート中を移動する塩化 物イオンは液相中にある塩化物イオンであると考えられ るため，構造物における塩化物イオンの存在状態を調査
することは環境作用を考慮した構造物の而入性評価の観 点から重要である. 塩害と中性化との複合劣化に関して は, かぶりコンクリートの中性化によって塩化物イオン が濃縮する現象が報告されており 18)，25)，実験に基づ く解析的な検討もある2，3），19）。中性化による塩化 物イオンの濃縮はコンクリート中における鉄筋の腐食に も影響すると考えられる ${ }^{20)}$.

塩害の場合，アルカリ環境における鉄筋表面の不働態 皮膜の存在条件に着目寸れば，コンクリート中における 鉄筋の腐食発生条件は, 細孔溶液中の塩化物イオン濃度 や塩化物イオン濃度と $\mathrm{pH}$ との関係 $(\mathrm{Cl} / \mathrm{OH}$ 比) で定義 される．また，腐食速度に関しても，孔食電位の低下や コンクリートの比抵抗は塩化物イオン濃度の影響を受け ると考えられる．このように，鉄筋腐食を対象とした場 合にも, 細孔溶液中の塩化物イオン濃度を詳細に検討寸 ることは非常に重要である. 鉄筋腐食に関わる細孔溶液 中の塩化物イオン濃度を議論するには, 塩化物イオンの 固定化性状を考慮する必要がある.

コンクリート中の塩化物イオン量の試験方法には, JCI-SC4およびこれを基にした JIS A 1154がある.これら の試験方法においては，抽出される塩化物イオンとして， 硝酸溶解性の塩化物イオンと温水で抽出される塩化物イ 
オンを対象としているが，維持管理の現状において，温 水に抽出される塩化物イオンの調査結果は十分に活用さ れていないと考えられる。

本論文では，コンクリート中において，細孔溶液中に ある塩化物イオンとセメント水和物に固定される塩化物 イオンが吸着平衡関係にあると考えて，その吸着平衡関 係を構造物の調査により得られた硝酸溶解性の塩化物イ オン量と温水で抽出される塩化物イオン量の調查値によ って検討した. また, 前述の吸着平衡関係に及ぼすコン クリートの中性化の影響を, 構造物の調査で得られたデ 一タによって明らかにすることを試みた。

なお，本論文で「中性化」と呼ぶ現象は厳密には炭酸 化であるが，一般的な表現として「中性化」と呼ぶこと とした.

\section{2. 塩化物イオンの存在状態}

本論文では，コンクリート中における塩化物イオンの 固定化性状を検討寸るにあたって，図-1 に示したよう に塩化物イオンの存在状態を整理し，それぞれについて 図に示したような呼称および記号を使用した.

全塩化物イオンおよび可溶性塩化物イオンは JCI-SC4 によって規定される硬化コンクリート中に含まれる塩化 物イオン量の指標である. 全塩化物イオンは, 硝酸溶解 法により測定される塩化物イオン量を指寸呼称であり, コンクリート中に含まれる塩化物イオンの総量に相当寸 る. 可溶性塩化物イオンは温水抽出法により測定される 塩化物イオン量を指寸呼称である.ささらに，固定塩化物 イオンはコンクリート中において静電相互作用によって 水和物に吸着していると考えられる吸着塩化物イオンと 水和物に化学的に固定されている固相塩化物イオンによ り構成されると考えられる $\left.{ }^{2)}, 12\right)$. 化学的に固定され る塩化物イオンの代表的なものはフリーデル氏塩である が，コンクリート中における塩化物イオンは各種のセメ ント鉱物あるいはセメントの水和物と反応して複塩を生 成するとの報告もある ${ }^{4)}$.

自由塩化物イオンは，コンクリートの液相中にある塩 化物イオンの呼称である. 可溶性塩化物イオンは, 自由 塩化物イオンの全部と固定塩化物イオンの一部により構 成されると考えられている2)。

なお，全塩化物イオンや可溶性塩化物イオンは，コン クリート質量に対する質量百分率で表し, 固定塩化物イ オンはセメント $1 \mathrm{~g}$ に対する質量比で表す. 自由塩化物 イオンはコンクリートの自由水容積に対する $\mathrm{mol}$ 比で表 す.これらの塩化物イオンを存在状態の区別無く呼ぶ場 合には塩化物イオン量と呼ぶ.

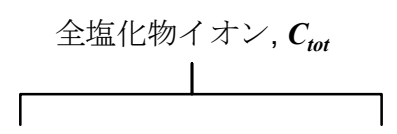

自由塩化物イオン, $\boldsymbol{C}_{\text {free }}$ 固定塩化物イオン, $\boldsymbol{C}_{\text {fixed }}$

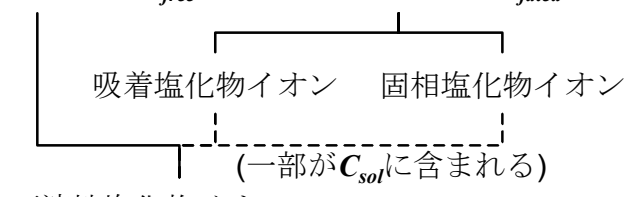

可溶性塩化物イオン, $\boldsymbol{C}_{\text {sol }}$

図-1＼cjkstart本論文における塩化物イオンの存在状態の分類

表-1 コンクリートの仕様

\begin{tabular}{l|l}
\hline \multicolumn{1}{c|}{ 項目 } & \multicolumn{1}{c}{ 仕様 } \\
\hline セメント種類 & 普通ポルトランドセメント \\
\hline 設計基淮強度 & $270 \mathrm{kgf} / \mathrm{cm}^{2} \quad\left(26.5 \mathrm{~N} / \mathrm{mm}^{2}\right)$ \\
\hline 粗骨材の最大寸法 & $25 \mathrm{~mm}$ \\
\hline スランプ & $15 \mathrm{~cm}$ \\
\hline 打設方法 & 配管-ポンプ压送 \\
\hline
\end{tabular}

\section{3. 海洋環境下の構造物の調査}

\section{（1）調査概要}

調查対象とした構造物は, 梁-スラブ構造の 2 つの栈 橋であり, 干満による海水の作用は受けないものの, 飛 沫帯にあって波浪によりしばしば海水が直接作用する環 境条件下で, 約 30 年間供用された. 構造物のコンクリ 一ト材料に関寸る情報は, 施工時の工事記録に残されて いた表-1に示した情報のみであった。

材料に関する調查は，主として梁部側面から，一部は 床版から，コンクリートコアを採取して実施した．コア の径は $10 \mathrm{~cm}$ とした. 調查構造物は 2 基あり, それぞれ コア記号 1-1 1-8 および 2-1〜2-6 の合計 14 箇所でコン クリートコアを採取した. 表-2 に各コア試料の採取部 位と中性化深さの測定值を示した。 また, 構造物の置か れる環境の気象情報を表-3に，コア採取位置の概要を 図-2に示した.

調査項目は塩化物イオン量の分布と中性化深さとした. 中性化深さは，コア試料を割裂し，割裂面にフェノール フタレイン $1 \%$ アルコール溶液を噴霧する方法で測定し た. 採取したコアを測定深度毎に厚さ $20 \mathrm{~mm}$ の円盤状試 料に切断し, 全粉砕して塩化物イオン量を測定した. 塩 化物イオン量の測定方法は JCI-SC4 に拠った. 分布の表 示には, 厚さ $20 \mathrm{~mm}$ の試料の平均深さを用いた.

\section{(2) 調査結果}

\section{a) 中性化深さ}

調査対象構造物の中性化深さは，表-2 に示したよう 
に，コア採取位置により変動があり $0.0 \mathrm{~mm} \sim 19.0 \mathrm{~mm}$ で あった．コア採取位置は海面上約 $3 \mathrm{~m}$ にあって, 調査位 置によっては比較的乾燥期間が長かったため中性化も進 行し, 波浪および飛沫によって塩化物イオンも供給され た箇所があったと考えられる.

図-2 に示した調查位置や方向と中性化深さの関係は 以下のように考察される. まず，同一部材であっても， 面の方向によって中性化深さが異なっており, 東面およ び南面の方が西面および北面と比較して中性化深さが大 きい傾向があった．また，構造物外縁の 1-1 や 1-3 では 中性化深さが $0.0 \mathrm{~mm}$ であったのに対して, 内側に位置 寸る梁の調査結果である 1-4，1-6，1-7では 20mm 程度で あった，これは，卓越する風向によって，構造物に作用 寸る波浪の影響が異なっていたためと考えられる．同様 に風向の影響として，構造物の平面的な位置で東側に位 置する部材では，波浪の影響が比較的小さかったため中 性化深さが大きくなったと考えられる，2-5 および 2-6 は構造物側面から採取したコンクリートコアによる結果 である. 2-5 では上部に障害物があって降雨の影響を受 けない環境であった. 2-6 では 2-5 と比較すると降雨の 影響を受けると考えられる部位であったため，2-6 では 2-5 と比較して中性化深さが小さかったと推察される. また，2-5 および 2-6 の調查位置は海面からの高さが他 の調査位置と比較して低かったため, 他の梁やスラブと 比較して中性化深さが小さかったと考えられる. このよ うに, 中性化深さの調査結果は, 構造物部材の波浪や降 雨による乾湿環境亡密接に関係していると考えられる.

ここでいう中性化深さとは, フェノールフタレイン 1\%アルコール溶液を噴霧したときに呈色しない部分の 表面からの深さであるが，その要因は，炭酸化と考えら れる. その他, 中性化の要因としては溶脱があるが, 構 造物の海面からの高さが $3 \mathrm{~m}$ 程度あり, 波浪の影響は受 けるものの, 中性化深さが大きいのは波浪の影響が少な かったと考えられる部位であることから，溶脱の影響は ほとんどなかったと考えられる.

中性化深さによって判別すれば, 塩化物イオン量の測 定における表層部 $20 \mathrm{~mm}$ の円板状試料は，一部または大 部分が中性化の影響を受けた部分を含む中性化混在部で ある. 一方, 表面から $40 \mathrm{~mm}$ よりも内部は未中性化部と みなせる. したがって, 表層 $20 \mathrm{~mm}$ における塩化物イオ ン量の調查結果と $40 \mathrm{~mm}$ 以深の塩化物イオン量の調査結 果とを比較検討寸ることによって，塩化物イオンの固定 化性状に及ぼす中性化の影響を検討した。

\section{b) 塩化物イオン濃度分布}

図-3 および図-4 に全塩化物イオン分布および可溶性 塩化物イオン分布の調査結果を示寸. 凡例には, 各分布 データのコア記号と中性化深さ(mm)を合わせて示した.
表-2 コア採取部位および中性化深さ

\begin{tabular}{|c|c|c|c|c|}
\hline $\begin{array}{l}\text { コア } \\
\text { 記号 }\end{array}$ & \multicolumn{2}{|c|}{ 部位 } & $\begin{array}{c}\text { 海面からの } \\
\text { 高さ* }{ }^{2} \text { m }\end{array}$ & $\begin{array}{c}\text { 中性化深 } \\
\text { さ, mm }\end{array}$ \\
\hline $1-1$ & \multirow{2}{*}{$\begin{array}{c}\text { 最外縁の梁 } \\
\text { (同一部材) }\end{array}$} & 北面 & 2. 990 & 0.0 \\
\hline $1-2$ & & 南面 & 2. 990 & 9.0 \\
\hline $1-3$ & 最外縁の梁 & 北面 & 2.990 & 0.0 \\
\hline $1-4$ & \multirow{2}{*}{$\begin{array}{c}\text { 内側の梁 } \\
\text { (同一部材) }\end{array}$} & 東面 & 2. 990 & 18.8 \\
\hline $1-5$ & & 西面 & 3. 140 & 0.8 \\
\hline $1-6$ & \multirow{2}{*}{$\begin{array}{c}\text { 内側の梁 } \\
\text { (同一部材) }\end{array}$} & 東面 & 3. 140 & 17.8 \\
\hline $1-7$ & & 西面 & 3. 140 & 19.0 \\
\hline $1-8$ & スラブ & 下面 & 3. 820 & 0.0 \\
\hline $2-1$ & 最外縁の梁 & 北面 & 3. 540 & 1.2 \\
\hline $2-2$ & \multirow{2}{*}{$\begin{array}{c}\text { 最外縁の梁 } \\
\text { (同一部材) }\end{array}$} & 東面 & 3. 540 & 8.3 \\
\hline $2-3$ & & 東面 & 3.540 & 13.3 \\
\hline $2-4$ & スラブ & 下面 & 3.690 & 1.3 \\
\hline $2-5$ & \multirow{2}{*}{$\begin{array}{c}\text { 配管橋基礎 } \\
\text { (同一部材) }\end{array}$} & 東面 & 1. 040 & 0.5 \\
\hline $2-6$ & & 東面 & 1. 040 & 4.3 \\
\hline
\end{tabular}

* : HWL からの高さ (HWL DL+0. 450, LWL DL+0. 170)

表-3 気象データの平年值(年) ${ }^{* 1}$

\begin{tabular}{c|c|c|c|c|c}
\hline $\begin{array}{c}\text { 平均気温 } \\
{ }^{\circ} \mathrm{C}\end{array}$ & $\begin{array}{c}\text { 最高気温 } \\
{ }^{\circ} \mathrm{C}\end{array}$ & $\begin{array}{c}\text { 最低気温 } \\
{ }^{\circ} \mathrm{C}\end{array}$ & $\begin{array}{c}\text { 平均風速 } \\
\mathrm{m} / \mathrm{s}^{* 2}\end{array}$ & $\begin{array}{c}\text { 日照時間 } \\
\text { 時間 }\end{array}$ & $\begin{array}{c}\text { 降水量 } \\
\mathrm{mm}\end{array}$ \\
\hline 13.5 & 17.2 & 10.2 & 3.5 & 1651 & 1775.8 \\
\hline
\end{tabular}

*1:気象庁ホームページより引用

$* 2:$ 卓越する風向は西
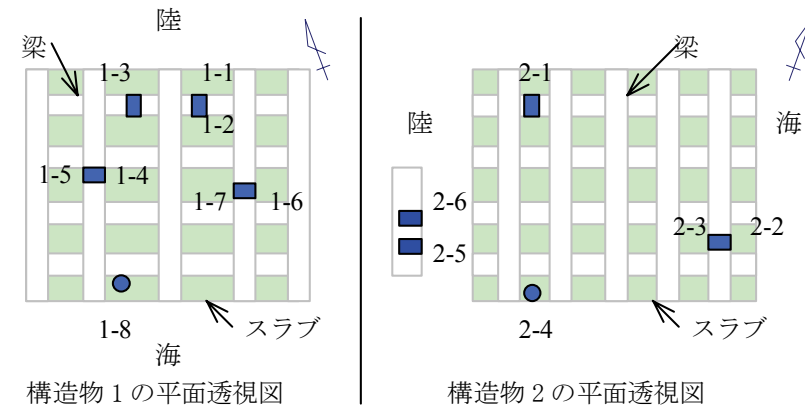

構造物 2 の平面透視図

図-2 コア採取位置の概要図

なお，ここでは塩化物イオン量の単位は気乾状態のコ ンクリートコアに対する質量百分率を用いた.

図は構造物毎に全塩化物イオン分布と可溶性塩化物イ オン分布を示したものであり，コアサンプル毎に深さ方 向の濃度分布を示した. 全塩化物イオンおよび可溶性塩 化物イオンともに塩化物イオン量の分布の全体的な傾向 は, 深部ほど濃度が低く, 表面から塩化物イオンが浸入 したことがわかる。腐食限界濃度を $1.2\left(\mathrm{~kg} / \mathrm{m}^{3}\right.$ of concrete） 1) とすれば，図の濃度単位では，0.05（mass\% of concrete）となり，サンプルによってばらつきはあるも 
のの，両構造物ともに表面から $100 \mathrm{~mm}$ 程度までの範囲 では多くの調査位置で腐食限界濃度を超えていた。

表面付近の塩化物イオン分布に着目すれば，全塩化物 イオン分布および可溶性塩化物イオン分布ともに，表層 部 $20 \mathrm{~mm}$ の塩化物イオン量よりも $50 \mathrm{~mm}$ 付近の塩化物イ オン量の方が高い凸形分布を示している場合と表面の濃 度が最も高い右下がりの分布を示している場合がある. 右下がりの分布の場合と比較して，凸形分布の場合の方 が $50 \mathrm{~mm}$ 付近の濃度は高い傾向がある. 1-8 のデータの ように中性化深さが $0 \mathrm{~mm}$ でも同様の傾向を示す場合が あり，可溶性塩化物イオンや全塩化物イオンの測定結果 からだけでは明確ではないものの，このような濃度分布 の傾向は，中性化の影響によるものと考えられる ${ }^{18)}$. すなおち, 中性化した部分では塩化物イオンの固定化能 力が低下し, 自由塩化物イオンが相対的に高くなる. そ のため, コンクリート中を移動可能な自由塩化物イオン の濃度勾配が大きくなることによって自由塩化物イオン
の移動が促進され, 未中性化部で再び固定される結果, 中性化部のフロントで濃度が高くなるといった機構であ る. 本構造物のように外部からの塩化物イオンの供給も あり, 中性化も進むような環境では，未中性化コンクリ 一トに浸入した塩化物イオンが中性化の進行によって中 性化のフロントで濃縮されたのか, 外来の塩化物イオン が固定能の低下した中性化部を通過することによって中 性化のフロントで濃度が高くなったのかは区別しがたい. 本論文では，これらの中性化のフロントで濃度が高くな る現象を区別なく中性化による濃縮と定義する.

以後の検討においては, 自由塩化物イオンの単位は硬 化コンクリート中の自由水量の容積に対するモル比

(mol/l) を用い, 固定塩化物イオンの単位はセメントに 対する質量比(mg/g_cement)を用いる. これは, 細孔溶液 中における塩化物イオン濃度と固定される塩化物イオン 量との関係を整理する場合に, セメント水和物に固定さ れる塩化物イオン量は液相の塩化物イオン濃度と関係し a) 全塩化物イオンの分布

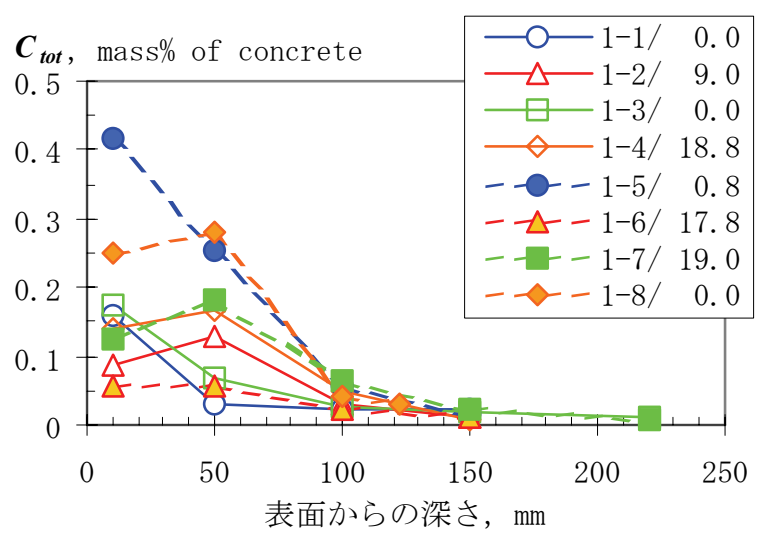

b)可溶性塩化物イオンの分布

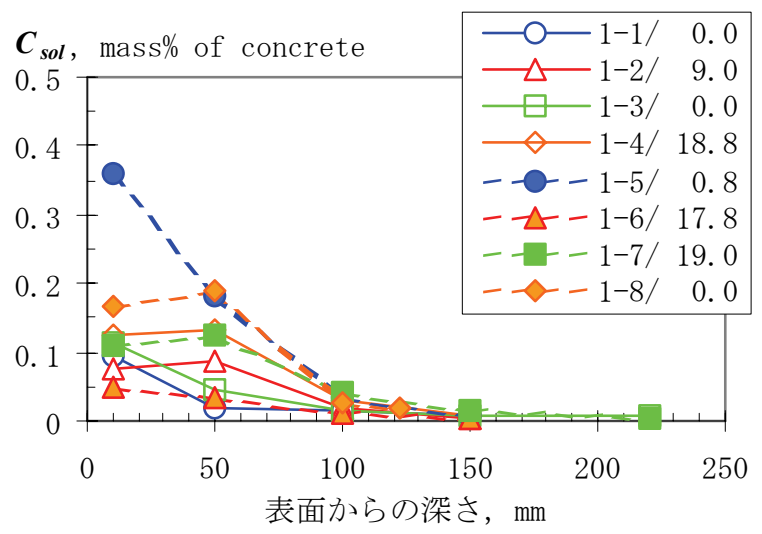

（凡例は，コア No/中性化深さ mm）

図-3 構造物 1 の塩化物イオン分布

a) 全塩化物イオンの分布

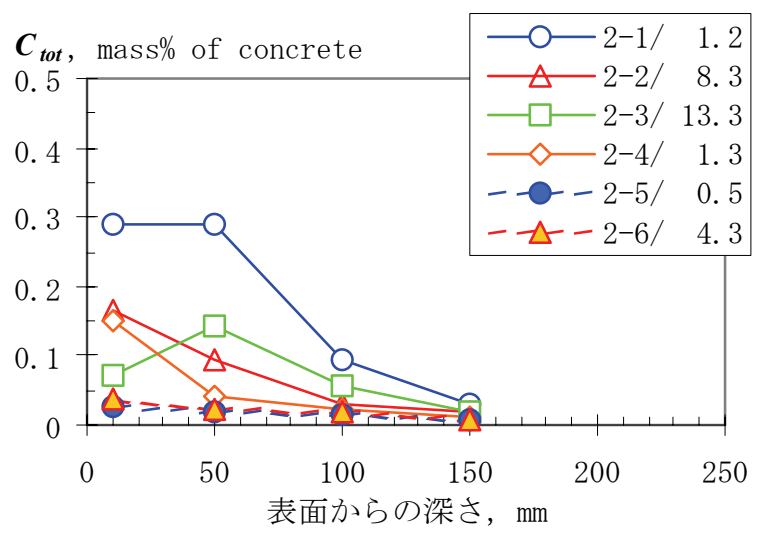

b)可溶性塩化物イオンの分布

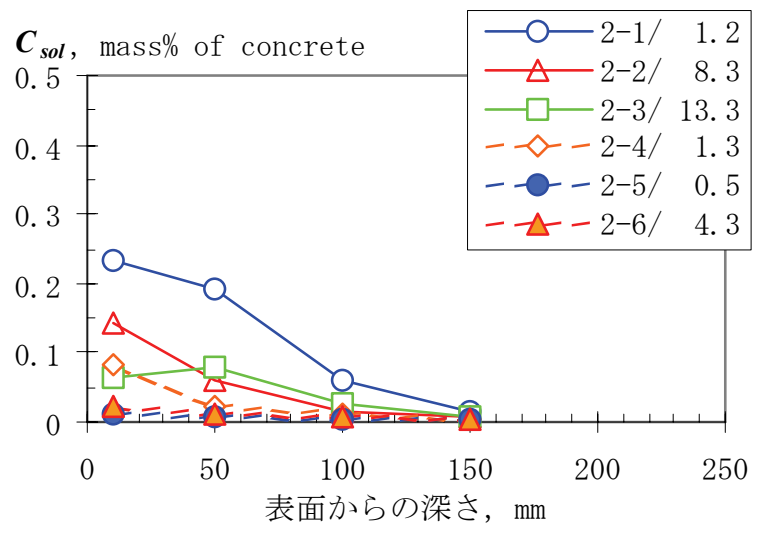

（凡例は，コア No/中性化深さ mm）

図-4 構造物 2 の塩化物イオン分布 
ていると考えられるためである. また, 吸着等温式の適 用にあたつて，構造物毎に配合条件や乾燥条件が異なる ことを考慮すれば，上記のような単位で整理した方が汎 用性が高いと考えられる。

ただし，調査データは細孔溶液の塩化物イオン濃度を 測定したものではないため, 既往の実験式 ${ }^{2)}$ を適用し て可溶性塩化物イオンから自由塩化物イオンを推定した。 この実験式は，JCI 法による可溶性塩化物イオンと高圧 抽出による細孔溶液の塩化物イオン濃度から求めた自由 塩化物イオン量との関係を定式化したものである.この 方法で換算される自由塩化物イオン量は，高圧抽出で得 られた任意の塩化物イオン濃度の細孔溶液によってコン クリート中の細孔が飽和されているときの塩化物イオン 量に相当する。したがって，構造物から採取された試料 であっても，任意の乾燥条件にある構造物における自由 塩化物イオンをそのまま評価することとは異なり, 吸着 等温線を調査データによって検討するにあたって, 得ら れた吸着等温線はサンプルの一定条件下での特性を評価 することにならざるを得ない.

任意の乾燥条件にある構造物の中では，乾燥の影響で 塩化物イオンが $\mathrm{NaCl}$ として析出している可能性がある. また，塩化物イオンの分析の過程では，室温で風乾する ことが規定されており，試料の実際の細孔溶液中の濃度 が高ければ風乾の過程で $\mathrm{NaCl}$ として析出している可能 性もある. しかし，得られた可溶性塩化物イオンの量が， 表乾状態のコンクリートにおける細孔溶液を飽和するよ うな量でなければ，析出した塩化物イオンは温水抽出の 過程で容易に抽出されると考えられることから，表乾状 態を前提とした検討においては塩化物イオンの析出の影 響はそれほど大きくないと考えられる．本論文で報告す るデータは，上述の実験式が作成された可溶性塩化物イ オンの範囲にあることからも実験式の適用は妥当だと考 えられる.

一方，中性化したコンクリートに対しては，上述の実 験式がそのまま適用できない可能性がある。細孔溶液中 にある塩化物イオンは中性化したコンクリートからも同 様に温水抽出されると考えられるが, 可溶性塩化物イオ ンに含まれると考えられる吸着塩化物イオンや固相塩化 物イオンの一部については，中性化を受けた場合に，温 水抽出のされやすさが変化するかどうかは十分明らかで ない. また，中性化による吸着サイトの変化の影響も考 えられる. 既往の研究では, 中性化したコンクリートの 細孔溶液を高圧抽出し, 前述の実験式と同様に可溶性塩 化物イオン量と自由塩化物イオン量との相関について検 討し, 中性化に伴う緻密化により吸着サイトが増加する ため，相対的に可溶性塩化物イオンに対する自由塩化物 イオンの量比が低下すると報告されている ${ }^{28)}$. しかし，
その変化量は僅かであり，本論文で扱う中性化部のデー 夕は，中性化部と未中性化部の混相であることから，影 響は小さいと考えて，未中性化部と同様の変換を行って 可溶性塩化物イオンから自由塩化物イオンを評価した.

ここで，実験式で算出される自由塩化物イオン量を液 相濃度である自由塩化物イオンに換算するにあたっては， 配合上の水およびセメントの単位量を用い，セメントの 結合水率を水結合材比 $17 \%{ }^{27)}$ として，単位水量加ら結 合水を差引くことによって細孔溶液量を求めた。単位の 換算には，コンクリートの配合条件が必要であるが，現 存する資料から得られた情報は，表-1 に示したコンク リートの仕様のみであった。 したがって，本論文では当 時の同種の構造物で使用された同様な設計基準強度の示 方配合を参考にして，水セメント比（W/C = 50\%），単 位セメント量 $\left(\mathrm{C}=320 \mathrm{~kg} / \mathrm{m}^{3}\right)$, 単位水量 $(\mathrm{W}=$ $\left.160 \mathrm{~kg} / \mathrm{m}^{3}\right)$ を仮定して濃度の換算を行なった。 コンクリ 一トの単位容積質量はコアを採取した状態での気乾密度 である $2350 \mathrm{~kg} / \mathrm{m}^{3}$ を用いた。

\section{4. 未中性化コンクリート中の塩化物イオンの固 定化性状}

\section{(1) 固定塩化物イオンと自由塩化物イオンの関係の吸着 等温式による整理}

細孔溶液中を移動する塩化物イオンは，正の電荷に帯 電した細孔表面の影響を受けるため，陽イオンよりも細

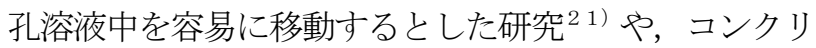
一ト中の塩化物イオンの移動において，正に帯電した細 孔壁への吸着を考慮することによって表層部における塩 化物イオンの濃縮をモデル化した研究がある ${ }^{3)}$. この ような，電気的な作用が生じているとすれば，液相中の 自由塩化物イオンと吸着塩化物イオンとの平衡関係は, 単分子層あるいは多分子層型の吸着を仮定した吸着等温 式により整理できると考えられる.

本論文では， $50^{\circ} \mathrm{C}$ 温水で抽出された可溶性塩化物イオ ンと $20^{\circ} \mathrm{C}$ 条件下で高圧抽出された自由塩化物イオン との相関により定式化された実験式を適用して，可溶性 塩化物イオンを自由塩化物イオンに換算した。 したがっ て，以降の検討で，いくつかの吸着等温式を適用するが， これらの吸着等温式は $20^{\circ} \mathrm{C}$ 条件下における吸着等温 式に相当する，吸着平衡には，当然ながら温度の影響が あるが， $20^{\circ} \mathrm{C}$ の温度条件は通常の構造物の温度条件とみ なせる。

単分子層あるいは多分子層の吸着を仮定した吸着等温 式に Langmuir型およびBET型がある22).

調査の結果得られた固定塩化物イオンを吸着量とし, 


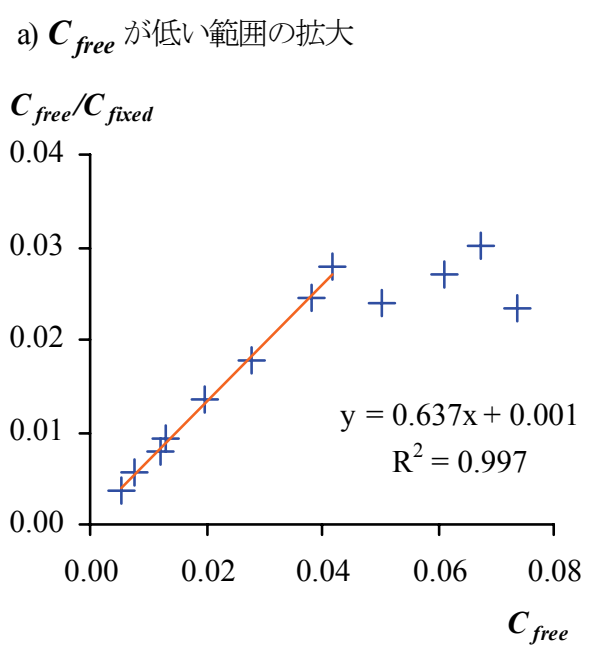

$$
\text { b) } 50 \mathrm{~mm} \text { 以深の調査データ全体 }
$$

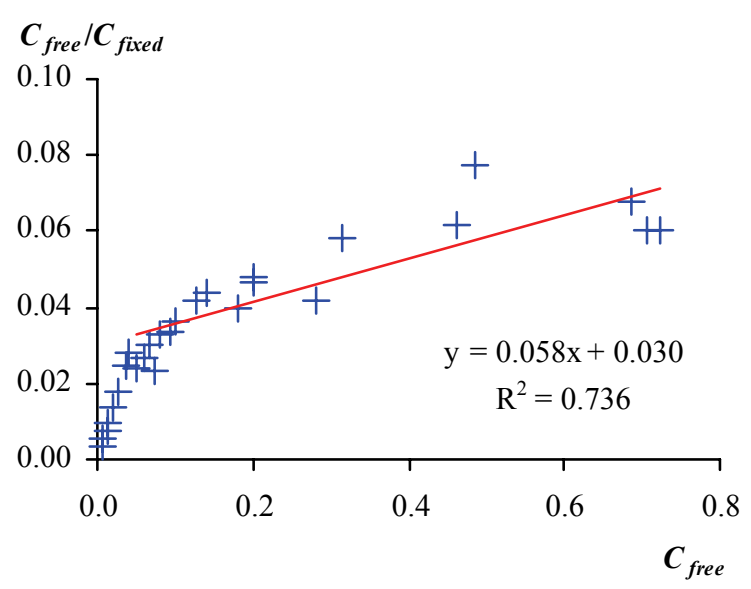

自由塩化物イオンは $\boldsymbol{C}_{\text {free }}=0.595 \boldsymbol{C}_{\boldsymbol{s o l}}-0.033$ （単位 $\mathrm{mass} \%$ cement） ${ }^{2)}$ で換算した後, $\mathrm{mol} / \mathrm{l}$ に換算した. 図-5＼cjkstart可溶性塩化物イオンから自由塩化物イオンを換算した場合の Langmuirプロット
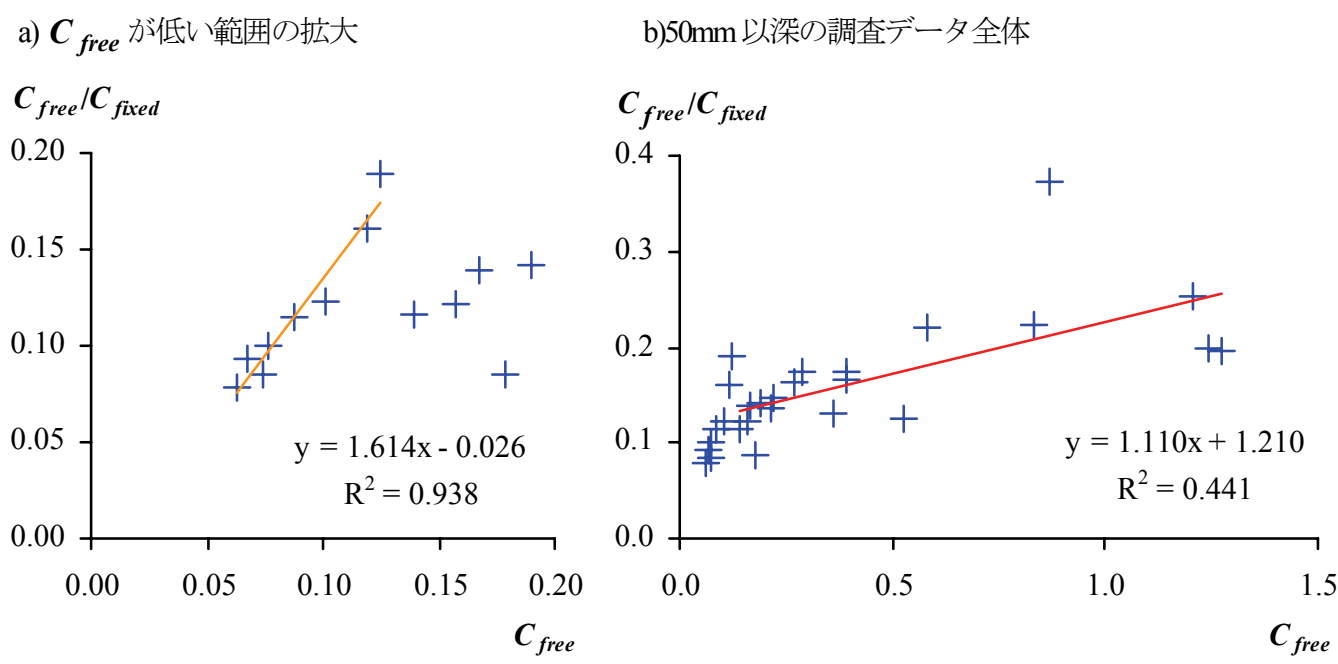

図-6 可溶性塩化物イオンを自由塩化物イオンとした場合の Langmuir プロット $\left(\boldsymbol{C}_{\text {free }}=\boldsymbol{C}_{\text {sol }}, \mathrm{mol} / \mathrm{l}\right)$

液相中の塩化物イオン濃度を自由塩化物イオンとすれば, 両者の関係は Langmuir 型の吸着等温式で式(1)にように 書ける.

$$
\frac{C_{\text {free }}}{C_{\text {fixed }}}=\frac{C_{\text {free }}}{v_{m, L}}+\frac{A}{v_{m, L}}
$$

ここに, $C_{f r e e}$ : 自由塩化物イオン $(=$ 液相の平衡濃 度) $(\mathrm{mol} / \mathrm{l}), \boldsymbol{C}_{\text {fixed }}$ : 固定塩化物イオン（=吸着量） $(\mathrm{mg} / \mathrm{g}), \boldsymbol{v}_{\boldsymbol{m}, \boldsymbol{L}}$ : Langmuir 型吸着等温式における飽和吸着 量 $(\mathrm{mg} / \mathrm{g}), \boldsymbol{A}:$ 係数 $(\mathrm{mol} / \mathrm{l})$, である.

式(1)から，X軸に $\boldsymbol{C}_{\text {free }}$ を，Y 軸に $\boldsymbol{C}_{\text {free }} / \boldsymbol{C}_{\text {fixed }}$ をとっ て調査データをプロット（Langmuir プロット）した場合 に，直線関係が得られれば調査データにおける吸着平衡 は Langmuir 型吸着とみなせる. 調査データに対する式
(1)の各係数は, Langmuir プロットにおける回帰直線の傾 きおよびy切片から求めることができる.

調査データのうち中性化の影響がないと考えられる深 さ50mm 以深のデータを抽出して Langmuir プロットした 結果を図-5 および図-6 に示した. 各々の図の右側のb) 図は深さ $50 \mathrm{~mm}$ 以深のデータ全てを示したものであり, 左側の a)図は， $\boldsymbol{C}_{\text {free }}$ が低い範囲を拡大して示したもの である. 図-5 と図-6 の違いは，調査データから自由塩 化物イオンを評価する場合に，図-5 は既往の実験式 ${ }^{2)}$ を適用して可溶性塩化物イオンから自由塩化物イオンを 換算した場合であり，図-6 は可溶性塩化物イオンを自 由塩化物イオンとみなした場合である.

図-5b)に示したように，調査データの Langmuir プロッ トの傾向は， $\boldsymbol{C}_{\text {free }}$ が大きくなるにしたがってばらつき が大きくなるとともに，傾きが小さくなる傾向があり， 調査データ全体に対しては明確な直線関係が得られなか 
った。一方， $\boldsymbol{C}_{\text {free }} \leq 0.042(\mathrm{~mol} / \mathrm{l})$ の範囲では，図-5a)に 示したように，データの Langmuir プロットは直線性が あると判断できる. そこで， $\boldsymbol{C}_{\text {free }}=0.042(\mathrm{~mol} / \mathrm{l})$ をさ い值として, 低濃度側と高濃度側の 2 つの領域に分けて 直線回帰した. 図のように, 低濃度側に比べて高濃度側 では大きく相関が低下寸る結果となった。この結果から， しきい值濃度以下の濃度範囲では, 液相の自由塩化物イ オンと固定塩化物イオンとは Langmuir 型の吸着として 整理することができるが，しきい值濃度以上の範囲では 別の機構を考える必要があると考えられた.

可溶性塩化物イオンを自由塩化物イオンとみなして同 様の整理を行なった結果を図-6 に示寸. 図-6 と図-5 と を比較すれば, 可溶性塩化物イオンを自由塩化物イオン とみなした場合よりも, 可溶性塩化物イオンから換算さ れた自由塩化物イオンを用いた場合の方が，直線回帰の 相関係数は大きくなる. これは, 可溶性塩化物イオンに は自由塩化物イオンの他, 温水抽出時に解離された固定 塩化物イオンも含まれるためと考えられる.

以後は, 図-5 に示したデータのように，可溶性塩化 物イオンから自由塩化物イオンを換算し, 自由塩化物イ オンを全塩化物イオンから差引いて求めた固定塩化物イ オンを用いて，両者の平衡関係についての検討を進める。

図-5a)における低濃度領域の Langmuir プロットに対し て直線回帰した結果得られた傾きおよび $\mathrm{Y}$ 切片と Langmuir 型吸着等温式の係数はそれぞれ以下のような関 係にある。

$$
\frac{1}{v_{m, L}}=0.637, \quad \frac{A}{v_{m, L}}=0.000607
$$

したがって, Langmuir 型吸着等温式の各係数は, $\boldsymbol{v}_{\boldsymbol{m}, \boldsymbol{L}}=1.57(\mathrm{mg} / \mathrm{g})$ および $\boldsymbol{A}=0.000953(\mathrm{~mol} / \mathrm{l})$ となる.

次に，単分子の吸着分子層の上に第 2 層以降の吸着を 考えた多分子層の吸着等温式を適用して, 多分子層の吸 着として調査データが整理可能から゙うかを検討した．多 分子層の吸着を仮定した吸着等温式としては BET 型の 吸着等温式がある. 調査データにおいて, 固定塩化物イ オンを吸着量とし，液相中の自由塩化物イオンおよび夜 相中の飽和塩化物イオン濃度を用いて BET 型の吸着等 温式を書けば式(3)となる。

$$
\frac{C_{\text {free }}}{C_{\text {fixed }}\left(C_{\text {sat }}-C_{\text {free }}\right)}=\frac{1}{v_{m} K}+\frac{K-1}{v_{m} K} \cdot \frac{C_{\text {free }}}{C_{\text {sat }}}
$$

ここに, $C_{\text {fixed }}$ : 固定塩化物イオン（=吸着塩化物イ
オン量) $(\mathrm{mg} / \mathrm{g}), \boldsymbol{v}_{\boldsymbol{m}}$ : BET 型吸着の飽和吸着量 $(\mathrm{mg} / \mathrm{g})$, $C_{s a t}$ : 液相の飽和塩化物イオン濃度 $(\mathrm{NaCl}$ 溶液の飽和濃 度から， $4.5 \mathrm{~mol} / \mathrm{l}$ とした)， $\boldsymbol{K}$ : 第 1 層の吸着強さを表す 係数, $C_{\text {free }}$ : 自由塩化物イオン (=液相の平衡濃度) (mol/l), である.

式(3)から，図-7 に示したような X 軸および $\mathrm{Y}$ 軸を選 んで調查データをプロット（BETプロット）した場合に， 直線関係が得られれば調查データにおける吸着平衡は BET型吸着とみなせる. 調査データに対する式(3)の各係 数は, BETプロットにおける回帰直線の傾きおよび $\mathrm{y}$ 切 片から求めることができる.

調査データのうち中性化の影響がないと考えられる深 さ50mm 以深のデータを抽出して BET プロットした結 果を図-7 に示寸. 図の右側の b) 図は深さ $50 \mathrm{~mm}$ 以深の データ全てを示したものであり, 左側のa)図は, $\boldsymbol{C}_{\text {free }} / \boldsymbol{C}_{\text {sat }}$ が小さな範囲を拡大して示したものである.

図-7b)に示したように, BET 型の吸着等温式を適用し た場合にも，基本的には Langmuir 型吸着等温式を適用 した場合と同様の傾向を示していたので, Langmuir プロ ットと同じしきい值濃度を仮定して（ $\boldsymbol{C}_{\text {free }}=0.042$ $\left.\mathrm{mol} / \mathrm{l}, \boldsymbol{C}_{\text {free }} / \boldsymbol{C}_{\text {sat }}=0.0093\right)$, 自由塩化物イオンの低濃 度領域と高濃度領域に区別して直線性を検討した．その 結果, 低濃度領域の回帰直線の相関係数は Langmuir 型 吸着等温式の場合とほぼ同じ相関係数となった。しきい 值より高い濃度領域に対しては，BET型吸着等温式の方 がやや相関が高かった．図-7a)における回帰直線の係数 と式(3)における BET 型吸着等温式の各係数との関係は 式(4)のように書ける.

$$
\frac{1}{v_{m} K}=0.000123, \frac{K-1}{v_{m} K}=0.644
$$

したがって, BET 型吸着等温式の各係数は, $\boldsymbol{v}_{\boldsymbol{m}}=1.55(\mathrm{mg} / \mathrm{g}), \boldsymbol{K}=5236$ となる.

単分子層吸着を仮定した Langmuir 型吸着等温式は BET 型吸着等温式の特別な場合である ${ }^{26)}$. BET 型吸着 等温式において, 液相濃度が液相の飽和濃度 $\boldsymbol{C}_{\text {sat }}$ に比 べて非常に低い場合には，BET 型吸着等温式における $\boldsymbol{C}_{\text {sat }} / \boldsymbol{K}$ は Langmuir型吸着等温式における係数 $\boldsymbol{A}$ に近づ き, BET 型吸着等温式は Langmuir 型吸着等温式と同じ 形になる．このとき，両吸着等温式の係数 $\boldsymbol{v}_{\boldsymbol{m}}$ と $\boldsymbol{v}_{\boldsymbol{m}, \boldsymbol{L}}$ は 同じ物理的意味を持つ. 図-5 における Langmuir 型吸着 等温式から得られた飽和吸着量 $\boldsymbol{v}_{\boldsymbol{m}, \boldsymbol{L}}$ と図-7 における BET 型吸着等温式から得られた飽和吸着量 $\boldsymbol{v}_{\boldsymbol{m}}$ は, それ ぞれ $\boldsymbol{v}_{\boldsymbol{m}, \boldsymbol{L}}=1.57(\mathrm{mg} / \mathrm{g})$ および $\boldsymbol{v}_{\boldsymbol{m}}=1.55(\mathrm{mg} / \mathrm{g})$ であり，ほ ぼ同じ值であるとみなせる，また，BET型吸着等温式に おける $\boldsymbol{C}_{\text {sat }} / \boldsymbol{K}$ と Langmuir 型吸着等温式における係数 $\boldsymbol{A}$ 


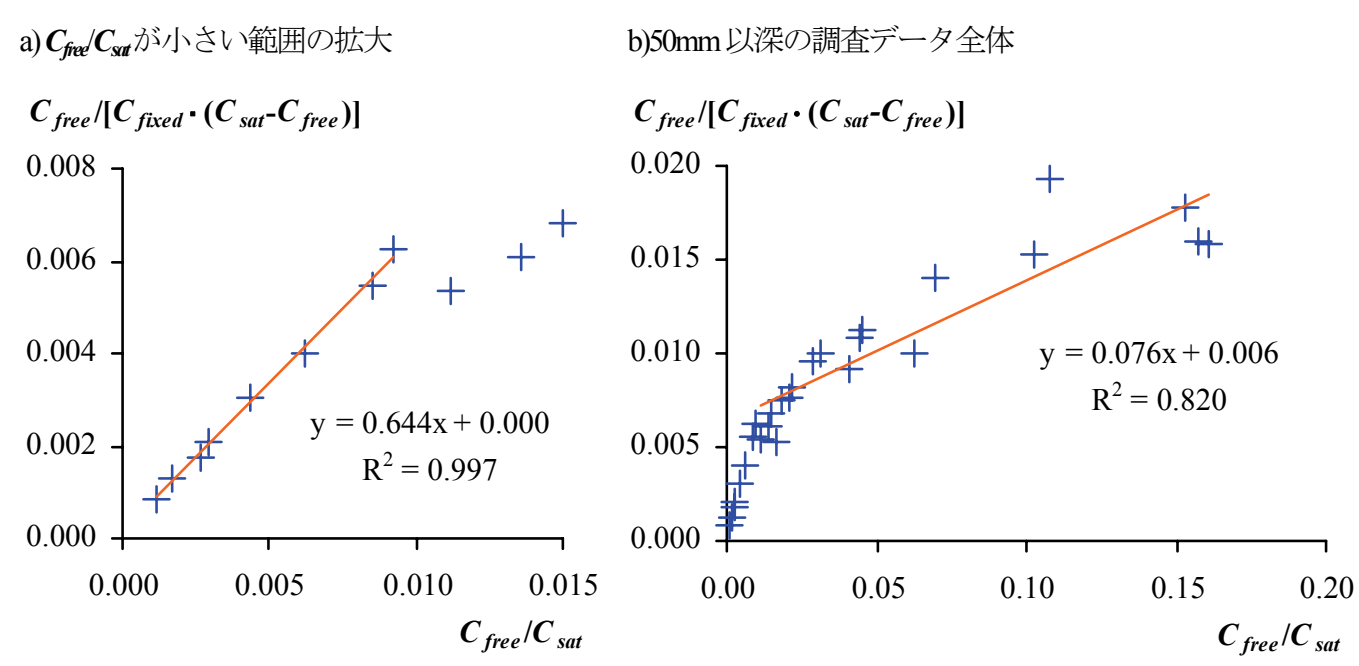

図-7 未中性化コンクリート中の塩化物イオンの BET プロット

は，それぞれ $\boldsymbol{C}_{\text {sat }} / \boldsymbol{K}=0.000859$ および $\boldsymbol{A}=0.000953$ であり 近い值となった.

以上から，調査データにおけるしきい值濃度よりも低 い濃度領域の吸着平衡は BET 型吸着等温式を用いても Langmuir 型吸着等温式を用いてもほぼ同じ相関で近似で きると考えられるが，低濃度領域における吸着は，単分 子層型の吸着に近い吸着平衡が生じていると考えられる。 高濃度領域に対しては，低濃度領域とは異なる吸着等温 式が適用されると考えられる.

既往の研究では，BET型吸着の第 2 層以降の吸着強さ を再考することで，高濃度領域に対する BET 型吸着等 温式の適用を検討した例もある ${ }^{7)}$ 。しかし，フリーデ ル氏塩の生成などの固相への化学的な固定が生じている ことを考慮すれば，固定塩化物イオンが全て物理吸着に よるモデルによって説明されないことはむしろ自然であ り，高濃度領域の吸着平衡に対して，単分子層あるいは 多分子層の吸着平衡といった物理的な吸着とは別の機構 を考えるのが妥当だと考えられる．したがって，BET型 および Langmuir 型の吸着等温式では十分な相関が得ら れなかった高濃度領域の吸着平衡に関して, 式(5)で表さ れる Freundlich 型の吸着等温式の適用を検討した. Freundlich 型の吸着等温式は経験式であるが，溶液から 固体表面への吸着に対してしばしば啇用される ${ }^{26)}$.

$$
\ln C_{\text {fixed }}=a \cdot \ln C_{\text {free }}+b
$$

ここに， $C_{\text {fved }}$ : 固定塩化物イオン量 $(\mathrm{mg} / \mathrm{g}$ cement), $\boldsymbol{C}_{\text {free }}$ : 自由塩化物イオン濃度 $(\mathrm{mol} / \mathrm{l}), \boldsymbol{a}, \boldsymbol{b}$ : 係数, である. 式(5)に示したように, Freundlich 型の吸着等温式は, 液相濃度の対数值と吸着量の対数值が比例すると仮定し たものである. 調査データを図-8 に示したような軸に 対してプロットした結果，データの直線性に関して， Langmuir 型および BET 型吸着等温式の場合とは異なり，

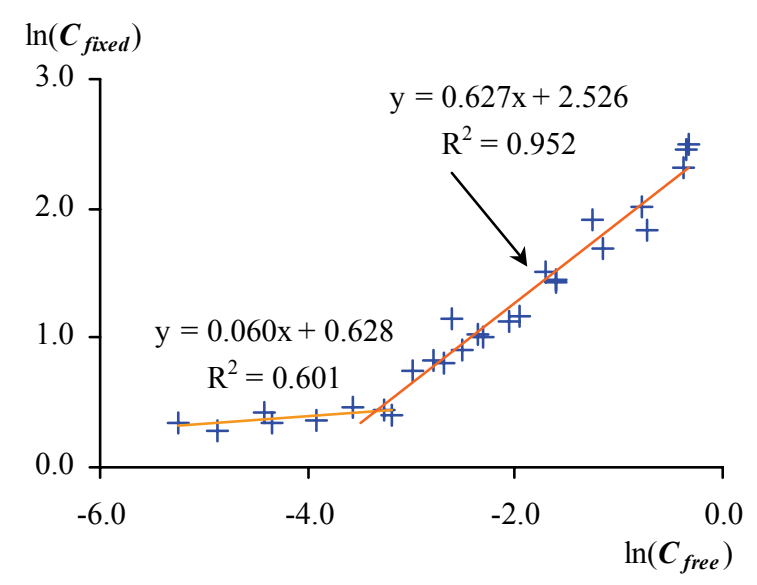

図-8 未中性化コンクリート中の塩化物イオンの Freundlich プロット

低濃度領域では相関が低いが，高濃度領域では高い相関 が得られた。高濃度領域における吸着平衡は Freundlich 型の吸着等温式で整理できると考えられる。ここで，高 濃度領域に対する Freundlich 型吸着等温式の各係数は, $a=0.627, b=2.53$ であった.

\section{（2）未中性化コンクリート中における塩化物イオンの吸 着と固定機構}

以上のように，未中性化コンクリート中における塩化 物イオンの吸着平衡について，低濃度領域では Langmuir 型吸着，高濃度領域では Freundlich 型吸着により説明で きることは，既往の研究6)とも一致するものである.

Langmuir 型および BET 型吸着等温式は表面への単分 子層あるいは多分子層の吸着といった物理的な意味付け がなされているが，Freindlich 型吸着等温式では物理的な 意味が不明確である。しかしながら，単分子層あるいは 多分子層といった物理的な吸着では上手く説明できない が液相にあるイオンと吸着されたイオンとの間に何らか 
の関係がある場合に Freindlich 型吸着等温式の適用性が 高いとも考えられる. コンクリート中における塩化物イ オンの固定は，通常は，フリーデル氏塩としてセメント 水和物に固定されることを指すように，細孔壁表面への 吸着だけでは説明できない. 以上から, Freindlich 型吸着 等温式の適用性が高いと考えられる濃度範囲では，フリ 一デル氏塩による固定やセメント水和物による層間吸着 などの機構により固相への固定が生じている場合に対応 するものと考えることもできる. この場合，固相への固 定は液相濃度がある程度高い場合に生じる現象であると 考えられる. 吉田ら ${ }^{11)}$ は，XRD 内部標準法を用いて， 外来塩化物イオンの固定化メカニズムについて検討し, フリーデル氏塩の生成は AFm のイオン交換によると報 告している. イオン交換過程では，塩化物イオン濃度が 高くなるにしたがって徐々にフリーデル氏塩が固定量の 大半を占め，イオン交換が終了すると C-S-H などへの吸 着量が増加すると推察している. なお，吉田らが検討し ている全塩化物イオン量は 0 および 0.16〜3.57(mass\% cement)の範囲であり，自由塩化物イオンとしては，本論 文で想定されたしきい值濃度を超える範囲に相当する. 吉田らが指摘しているように，固相への塩化物イオンの 固定は液相濃度に依存することを考慮すれば，コンクリ 一ト中に浸入した塩化物イオンの固定機構は, 図-9に 示したような概念図で表されると考えられる. すなわち， 1)液相濃度がしきい值濃度以下では細孔壁への吸着が先 行して生じる. この領域の吸着等温式は Langmuir 型で 整理できる．2)液相濃度がしきい值濃度を超えると， $\mathrm{AFm}$ のイオン交換と共に固相への固定が生じ，吸着等 温式は Langmuir 型あるいは BET 型ではなく, Freundlich 型で整理できると考えられる.

したがって，自由塩化物イオンと固定塩化物イオンの 関係は, Langmuir 型の吸着等温式と Freundlich 型の吸着 等温式とが複合した機構として説明される. 本論文にお ける調査データに対しては, 低濃度領域の Langmuir 型
吸着等温式および高濃度領域の Freundlich 型吸着等温式 の交点を考慮し，自由塩化物イオン $0.035(\mathrm{~mol} / \mathrm{l})$ をしい 值として，式(6)のような自由塩化物イオンと固定塩化物 イオンの関係式で整理される。ここで，固定塩化物イオ ンは吸着塩化物イオンと固相塩化物イオンの総量を表す.

$$
\left.\begin{array}{ll}
C_{\text {fixed }}=v_{\boldsymbol{m}, \boldsymbol{L}} \frac{\boldsymbol{C}_{\text {free }}}{\left(\boldsymbol{C}_{\text {free }}+\boldsymbol{A}\right)} & \left(\boldsymbol{C}_{\text {free }}<0.035\right) \\
\boldsymbol{C}_{\text {fixed }}=\exp \left(\boldsymbol{a} \cdot \ln \boldsymbol{C}_{\text {free }}+\boldsymbol{b}\right) & \left(\boldsymbol{C}_{\text {free }} \geq 0.035\right)
\end{array}\right\}
$$

ここに，未中性化コンクリート中の塩化物イオンに対 する各係数は, $A=0.000953, v_{m, L}=1.570, a=0.627, b=2.526$ である。なお，塩化物イオンの単位はそれぞれ， $C_{\text {free }}$ : 自由塩化物イオン $\mathrm{mol} / \mathrm{l}, \boldsymbol{C}_{\text {fixed }}$ : 固定塩化物イオ ン mg/g_cementである.

式(6)による自由塩化物イオンと固定塩化物イオンの関 係を図-10 に示す. 図の左図は低濃度側を拡大して示し たものである. なお, 式(6)は未中性化部の自由塩化物イ オンと固定塩化物イオンの関係式であり, 中性化部に対 しては係数が異なる. 図には既往の研究 $\left.\left.{ }^{2)}, 6\right), 15\right)$ にる Freundlich 型の実験式から単位を換算して求めた自由塩 化物イオンと固定塩化物イオンの関係も示した. 眓に示 した既往の研究結果は，いずれも普通ポルトランドセメ ントを対象とした実験結果である.

文献 2)の実験式は，本論文において求められた式(7)に 示した Freundlich 型の吸着等温式とほぼ一致している. 図-10a)に示した $0.1 \mathrm{~mol} / \mathrm{l}$ 以下の濃度範囲では，文献 6)お よび文献 15)の実験式は, 調査值よりも固定塩化物イオ ンが高く評価されている. 図-10b)に示した濃度範囲で は，文献 6の実験式は自由塩化物イオンおよそ $0.4 \mathrm{~mol} / \mathrm{l}$ 以下の範囲では式(7)と概ね一致しているとみなせるが, 0.4mol/1 を超える範囲では式(6)よりも固定塩化物イオン が低く評価されている. 文献 15)の実験式は自由塩化物

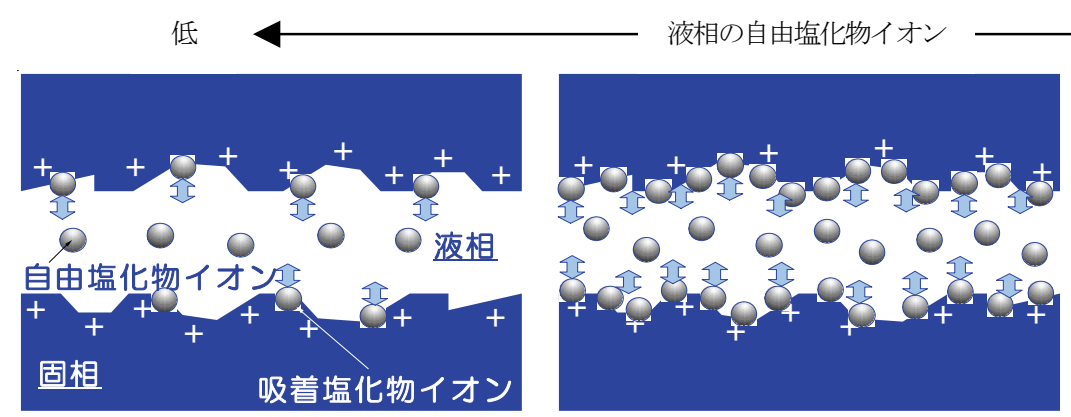

1)液相 Cl濃度がしきい值濃度以下では, 細孔壁への単分子層型に近い吸着が先行 寸る. 細孔壁への吸着量は, Langmuir型吸着の飽和吸着量以上にはならない.

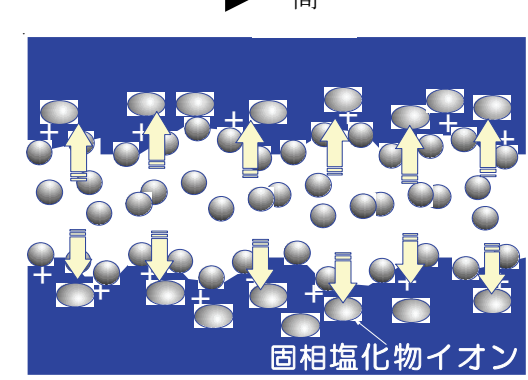

2)液相 Cl濃度がしきい值濃度を超えると固相へ の固定が生じる。この領域の吸着平衡は, Freundlich型の吸着等温式で表される.

図-9 コンクリート中における塩化物イオンの固定化性状 
a)低濃度側拡大

$\boldsymbol{C}_{\text {fixed }}, \mathrm{mg} / \mathrm{g}$ cement

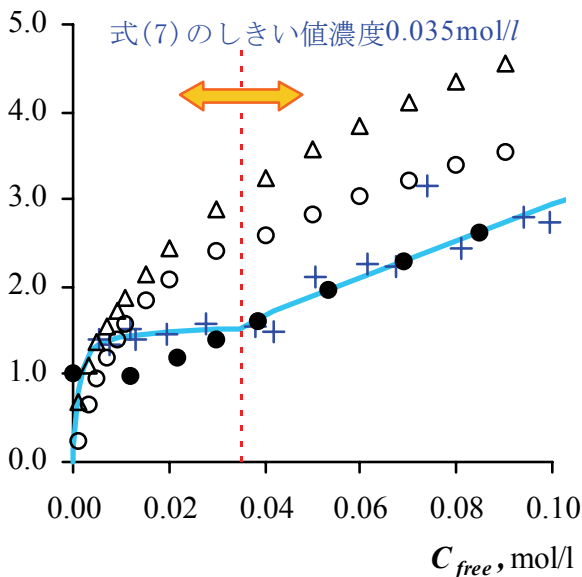

b ）高濃度側

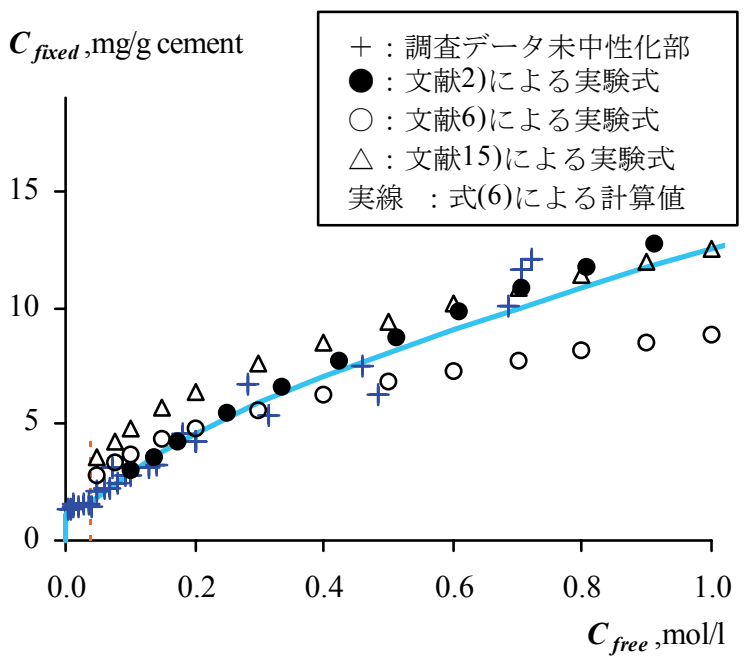

文献 6）では，固定塩化物イオン量は C-S-H,gellg に対する質量で表されている. ここでは，比較のため C-S-H の $\mathrm{SiO}_{2} / \mathrm{CaO}$ 比を 1.7

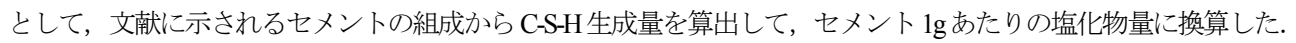

文献 15）では，固定塩化物イオン量は $\mathrm{W} / \mathrm{C}=0.5$ のセメントペーストの $105^{\circ} \mathrm{C}$ 乾燥質量 $1 \mathrm{~g}$ に対寸る質量で表されている. ここでは 比較のためセメントの結合水率を 0.17 とてて゚ーストの $105^{\circ} \mathrm{C}$ 乾燥質量を求めて, セメント $\lg$ あたりの塩化物量に換算した.

図-10 未中性化コンクリート中の自由塩化物イオン濃度 $\boldsymbol{C}_{\text {free }}$ と固定塩化物イオン量 $\boldsymbol{C}_{\text {fved }}$ の関係

イオン $1.0 \mathrm{~mol} / \mathrm{l}$ までの範囲では式(6)に近い傾向を示して いるが，これ以上の濃度では式(6)よりも固定塩化物イオ ンが低く評価されている.

文献 6)おび文献 15)では，浸漬法により平衡に達し た浸漬溶液の塩化物イオン濃度を自由塩化物イオンとし， 溶液濃度の減少量を固定塩化物イオンとしている. 一方, 文献 2)では，高圧抽出法によって抽出された細孔溶液の 塩化物イオン濃度と自由水量から自由塩化物イオン量を 評価し，全塩化物イオン量から自由塩化物イオン量を差 引くことによって固定塩化物イオンを評価している.こ れらの自由塩化物イオンや固定塩化物イオンの評価方法 が異なることが自由塩化物イオンと固定塩化物イオンと の関係に影響していると考えられる.

本論文では，文献 2)の実験式を適用して可溶性塩化物 イオンから自由塩化物イオンを評価したため, 文献 2)の 実験式と一致する結果となっている可能性がある. 文献 6)と文献 15)の実験結果は，同じ実験方法を適用してい ても, 固定塩化物イオンの単位が異なっていた. ここで は，単位を統一するための十分な情報が得られなかった ため，いくつかの仮定のもとで比較せざるを得なかった。 ここで仮定した数值が異なれば比較結果も変わる. しか しながら, 式(6)は自由塩化物イオンが $1.0 \mathrm{~mol} / \mathrm{l}$ 程度まで の範囲では既往の研究結果と概ね一致している. なお, 低濃度領域で観察される Langmuir 型吸着の飽和吸着量 は，構造物で観察される塩化物イオン量と比較してかな
り小さく，一般に，コンクリート中で固定される塩化物 イオンのほとんどは Freundlich 型吸着等温式で近似でき るとみなせる。

\section{5. 中性化による固定化性状の変化}

以上の自由塩化物イオンと固定塩化物イオンとの関係 は，深度 50mm 以深のデータを用いた検討結果であり， 未中性化部の塩化物イオンの固定化性状について検討し たものである。中性化深さの調査結果から, 表層部 $20 \mathrm{~mm}$ ではサンプルの一部または大部分が中性化してい たと判断できるので，ここでは各測点の表層部の自由塩 化物イオンおよび固定塩化物イオンの関係を整理した。

各測点の表層部の塩化物イオンの調査結果において, 各試料の自由塩化物イオンは未中性化部における低濃度 領域と高濃度領域とのしきい值濃度を超える濃度であつ た. したがって，まず，しきい值濃度以上の自由塩化物 イオン濃度領域に対して Freundlich 型の吸着を想定して, 自由塩化物イオンと固定塩化物イオンの関係を整理した。 表層部のデータを Freundlich プロットした結果を図-11 に 示す. 図には比較のため未中性化部のデータに対する回 帰直線も示した. 眓に示したように，表層部分のデータ についても，未中性化部と同じしきい值濃度以上の範囲 では，自由塩化物イオンと固定塩化物イオンの関係は 
Freundlich 型の吸着等温式で整理できると考えられる. ただし，表層部のデータであっても，中性化深さがサン プルの厚さ $20 \mathrm{~mm}$ に対して小さい場合には，自由塩化物 イオンと固定塩化物イオンの関係は未中性化部の回帰直 線に近い傾向を示している. 中性化深さが, サンプルの 厚さ $20 \mathrm{~mm}$ に対して同等程度の深さの場合には，未中性 化部に対する吸着等温線と比較して, 同じ自由塩化物イ オンに対する固定塩化物イオンが小さい傾向があり，図 に示したように固定塩化物イオンが小さくなる方向に平 行移動した直線が想定される. このように, 中性化によ って固定塩化物イオンが小さくなるといった傾向は，中 性化によって固定されていた塩化物イオンが液相中に解 離するといった考え方 ${ }^{18)}$ と一致するものである.

本論文においては，Freundlich 型の吸着を想定した結 果，中性化したコンクリート中における固定塩化物イオ ンの解離は，固定塩化物イオンの対数值が中性化により ある一定の割合で減少するモデルが想定された.

ただし，調査結果では，しきい值濃度よりも自由塩化 物イオンが小さい範囲のデータが得られていないため, 中性化によってしきい值濃度以下の領域に対する Langmuir 型を仮定した吸着がどのように変化するか，あ るいは変化しないかについては明らかでない.しかし， 中性化によってセメント水和物が炭酸化され, 細孔壁を 形成する水和物の組成や組織が変化するとすれば，単分 子層型の吸着を仮定している低濃度側の飽和吸着量が中 性化の影響によって変化したり, 単分子層型の吸着平衡 自体が観察されない場合も考えられる。ここでは，しき い值濃度は未中性化部と同じ濃度を仮定し，低濃度側の 中性化による吸着等温線の変化の予想として，関数形は 式(7)と同等として， Langmuir 型吸着における飽和吸着量 $\left(v_{m, L}\right)$ が減少することを仮定した結果, 図-12 に示し
たような吸着等温線が想定された. この時, 中性化部に 対する吸着等温式の各係数は, $A=0.000953, \boldsymbol{v}_{\boldsymbol{m}, \boldsymbol{L}}=0.839$, $a=0.627, b=1.90$ となった. ここで, 中性化部に対する係 数 $\boldsymbol{A}$ は, 中性化混在部についての低濃度領域のデータ が十分でないため, 中性化によって係数 $\boldsymbol{A}$ が変化する かどうかが明確に判断できなかったこと，および，前述 のように, 固定塩化物イオンのほとんどは Freundlich 型 の吸着で整理できると考えられることから，未中性化部 に対する係数 $\boldsymbol{A}$ と同じ值とした. 中性化部に対する係 数 $\boldsymbol{a}$ は，図-11 に示した中性化部のコンクリートで想定 される直線の傾きを表す係数である. 中性化部に対する

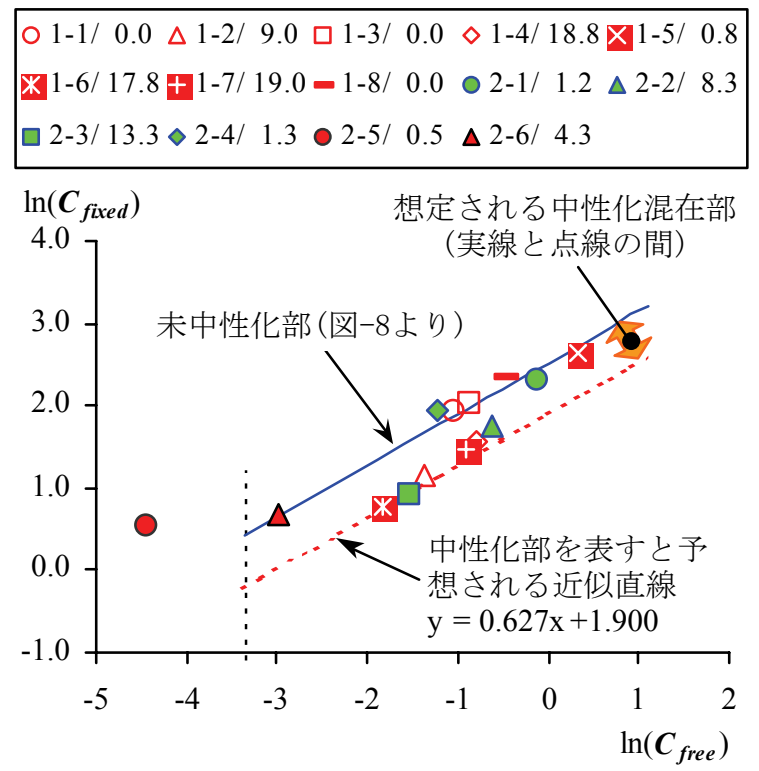

凡例は, コアNNo. /中性化深さ $(\mathrm{mm})$ を示す.

図-11 中性化部あるいは中性化混在部コンクリート中の 塩化物イオンの Freundlichプロット a)低濃度側拡大（予想）

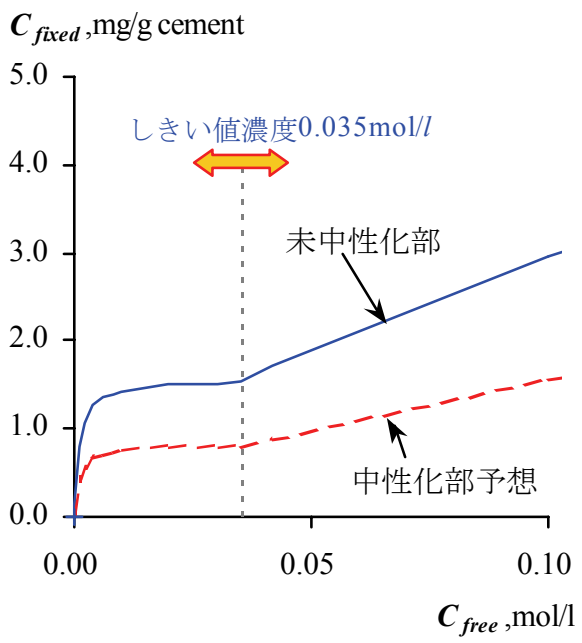

b ）高濃度側

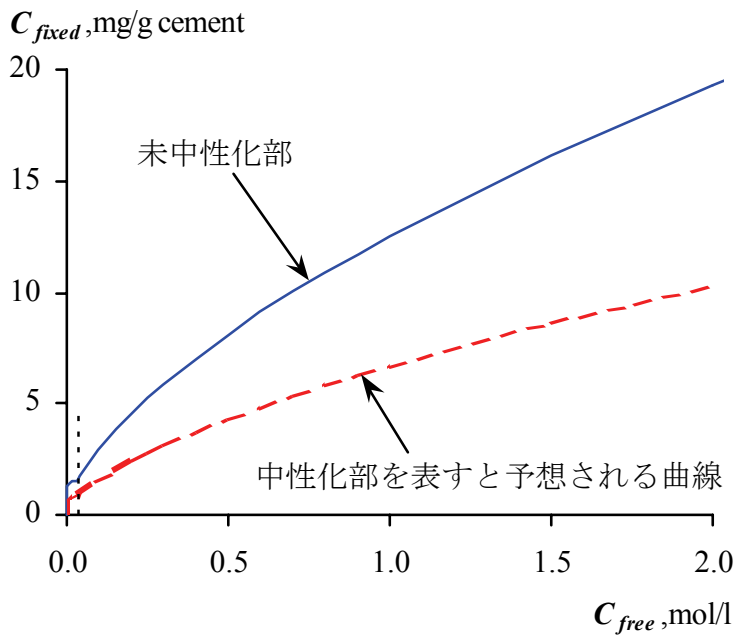

図-12 中性化部のコンクリートで想定される自由塩化物イオン濃度 $\boldsymbol{C}_{\text {fin }}$ と固定塩化物イオン $\boldsymbol{C}_{\text {frver }}$ の関係 
係数 $\boldsymbol{a}$ は, 中性化部が混在する表層部データが, 中性化 部に対応する吸着等温線と未中性化部に対応する吸着等 温線の間にプロットされるべきであると考えて, 中性化 深さが表層サンプルの厚さ $20 \mathrm{~mm}$ に対して同等の深さで あった 1-4，1-6，1-7，2-3 の位置を考慮した結果, 未中 性化部に対する係数 $\boldsymbol{a}$ と同じ值とした.

以上から, 未中性化部および中性化に対する吸着等温 式の各係数はそれぞれ表-4のように整理される.

\section{6. 乾燥および中性化による吸着平衡の移動}

前章までの検討の結果得られた, 表-4 に示した吸着 等温式の各係数は未中性化部と中性化部での吸着平衡の 変化を表すものである. 常に吸着平衡関係が成り立つと 仮定すれば，コンクリートが乾燥することによっても， 液相濃度の上昇によって吸着平衡が移動することになる。 このような影響を, 自由塩化物イオンと固定塩化物イオ ンの軸上で表せば図-13 のようになる。図には，未中性 化部および中性化部の吸着等温線と, 全塩化物イオンが 一定の条件下で含水比が異なる場合の自由塩化物イオン と固定塩化物イオンの関係を直線(I)および直線(II)で示し た.

今, 着目しているコンクリート要素において，塩化物 イオンの出入りが無いとすれば，コンクリートの乾燥が 進めば液相中の水分が減少することによって, 液相の水 量に対する濃度である自由塩化物イオンは増加する. 図 において, 全塩化物イオン一定の線である(I)は含水比の 低下と共に(II)に移動する.このとき, 全塩化物イオン 一定の条件下で自由塩化物イオンと固定塩化物イオンの 平衡は, 当初の全塩化物イオンにおける点 $\boldsymbol{A}$ から, 線 (II) と未中性化部の吸着等温線との交点である点 $\boldsymbol{B}$ に移 動すると考えられる. 吸着等温線には曲率があるため, 乾燥に伴う吸着平衡の移動により, 自由塩化物イオンの 割合が増加する. コンクリートが表面からの一面乾燥を 受ける場合に, 内部から表面方向への水分の移動と共に 塩化物イオンも移動すること, 水分勾配が生じることに よって表面付近の塩化物イオンの濃度が高くなる濃度勾 配が生じること, 含水率の低下によって見掛けの拡散係 数が低下寸ることなどの理由により表面付近では塩化物 イオンが濃縮すると考えられる2，3，23)，24)。これ らのメカニズムに加えて, 乾燥による濃度変化に起因す る吸着平衡の移動もまた, 自由塩化物イオンの濃度勾配 を大きく寸る作用があると考えられる.

次に，想定しているコンクリート要素において水分お よび塩化物イオンの出入りが無く, コンクリートが中性 化したとすれば，全塩化物イオン一定の条件のもと平衡
表-4 未中性化部と中性化部の吸着等温式の係数

\begin{tabular}{c|c|c}
\hline 係数 & 未中性化部 & 中性化部 \\
\hline $\boldsymbol{A}$ & 0.000953 & 0.000953 \\
\hline $\boldsymbol{v}_{\boldsymbol{m}, \boldsymbol{L}}$ & 1.570 & 0.839 \\
\hline $\boldsymbol{a}$ & 0.627 & 0.627 \\
\hline $\boldsymbol{b}$ & 2.526 & 1.900 \\
\hline
\end{tabular}

表中の各係数は下に示寸式(6)の係数に対応する.

$$
\left.\begin{array}{ll}
\boldsymbol{C}_{\text {fixed }}=\boldsymbol{v}_{\boldsymbol{m}, \boldsymbol{L}} \frac{\boldsymbol{C}_{\text {free }}}{\left(\boldsymbol{C}_{\text {free }}+\boldsymbol{A}\right)} & \left(\boldsymbol{C}_{\text {free }}<0.035\right) \\
\boldsymbol{C}_{\text {fixed }}=\exp \left(\boldsymbol{a} \cdot \ln \boldsymbol{C}_{\text {free }}+\boldsymbol{b}\right) & \left(\boldsymbol{C}_{\text {free }} \geq 0.035\right)
\end{array}\right\} \quad \text { (6) 再掲 }
$$

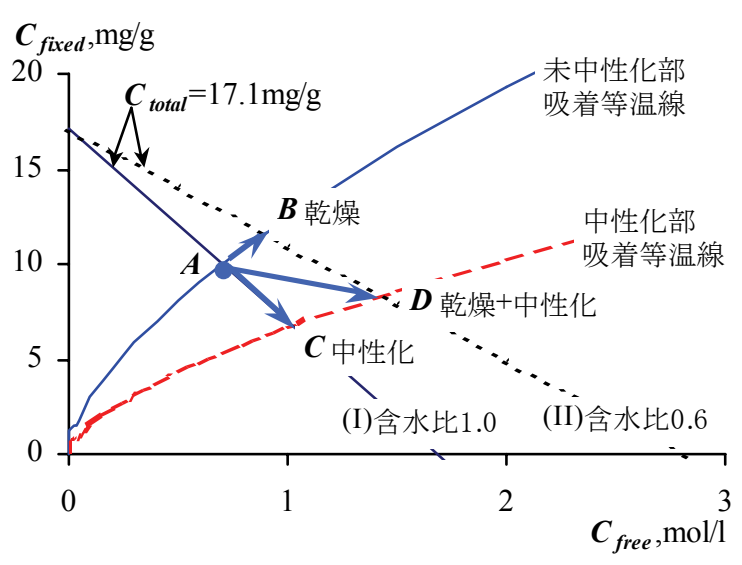

図-13乾燥および中性化による吸着平衡の移動

濃度は点 $\boldsymbol{A}$ から点 $\boldsymbol{C}$ に移動し, 液相の自由塩化物イオ ンは増加し固定塩化物イオンは減少すると考えられる.

乾燥および中性化が作用する場合には，図において点 $\boldsymbol{A}$ から点 $\boldsymbol{D}$ への変化として表される. 点 $\boldsymbol{A}$ から点 $\boldsymbol{C}$, 点 $D \sim$ 平衡の移動は, 自由塩化物イオンの増加により, 中性化部と未中性化部との境界において自由塩化物イオ ンの濃度勾配を大きく寸る作用がある. コンクリートの 中性化はコンクリートの飽水度が低い条件下で生じると 考えられるので, 構造物において中性化と乾燥が同時に 作用する状況はたびたび生じていると考えられる.

\section{7. 結論}

本論文では，構造物の調査で得られた全塩化物イオン 分布, 可溶性塩化物イオン分布および中性化深さの調查 結果に基づいて，コンクリート中の塩化物イオンの中性 化部および未中性化部における固定化性状の変化につい て検討した. 得られた知見は以下のようにまとめられる. （1）コンクリート中における塩化物イオンの固定化性 状は, 可溶性塩化物イオンから換算された液相中の自由 塩化物イオンと固定塩化物イオンとの吸着平衡として整 
理することができると考えられる．ここで，固定塩化物 イオンは，フリーデル氏塩としてセメント水和物に固定 されている塩化物イオンおよび水和物に吸着されている 塩化物イオンにより構成されるものとした. 本論文で得 られた未中性化部の吸着等温線は, 既往の研究結果とも 概ね一致していた。

（2）自由塩化物イオンと固定塩化物イオンとの関係を 吸着平衡として整理した結果, 可溶性塩化物イオンから 換算された液相の自由塩化物イオン $0.035(\mathrm{~mol} / \mathrm{l})$ をし きい值として，自由塩化物イオンがしきい值以下の場合 には Langmuir 型吸着等温式で整理でき，しきい值以上 の場合には Freundlich 型吸着等温式で整理できると考え られる.このしきい值は相当に小さな值であり, 構造物 の耐久性を検討するには，実用上は Freundlich 型吸着と みなしてよいと考えられた.

（3）中性化部と未中性化部のコンクリート中ではそれ ぞれ，異なる塩化物イオンの吸着平衡が生じていると考 えられた。

（4）中性化による吸着平衡の変化によって, 中性化し たコンクリート中では, 液相中の自由塩化物イオンと平 衡する固定塩化物イオンが低下寸ることによって, 全塩 化物イオンに占める自由塩化物イオンの割合が大きくな ると考えられる.

\section{参考文献}

1) 土木学会 : 2002年制定コンクリート標準示方書 [維持管理 編] , 2002.

2) 丸屋 剛: コンクリート中の塩化物イオン移動に関する解析 手法の構築, 東京大学学位論文, 1995.

3) 丸屋 剛, Tangtermsirikul Somnuk, 松岡康訓 : コンクリート表層 部における塩化物イオンの移動に関するモデル化，土木学 会論文集，No.585／V-38，pp.79-95，1998.

4) 後藤誠史, 常谷正己, 柳田洋明, 近藤連一 : セメント硬化体 中の塩素イオンの拡散, 窸業協会誌，Vol.87，No.3，pp.127133, 1979.

5) 平尾 宙: セメントによる塩化物イオンの固定に関する研究, コンクリート工学, Vol.42, No.11, pp.55-61, 2004.

6) Tang, L., and Nilsson, L.-O.: Chloride binding capacity and binding isotherms of OPC pastes and mortars, Cement and Concrete Research, Vol.23,pp. 247-253, 1993.

7) Tang, L., and Nilsson, L.-O.: Chloride binding isotherms -an approach by applying the modified BET equation, Chloride Penetration into Concrete, Proceedings of the International RILEM Workshop, ISBN:2-912143-00-4, pp. 36-42, 1995.

8) Beaudoin, J.J., Ramachandran, V.S. and Feldman, R.F. : Interaction of chloride and C-S-H, Cement and Concrete Research, Vol.23, pp. 247-253,
1993.

9) 中村明則, 坂井悦郎, 西澤賢一, 大場陽子, 大門正機 : ケイ酸力 ルシウム水和物による塩化物イオン, 硫酸イオンおよびリ ン酸イオンの吸着, 日本化学会誌, No.6, pp.415-456, 1999.

10) Nielsen, E.P., Herfort, D., Geiker, M.R. : Binding of chloride and alkalis in Portland cement systems, Cement and Concrete Research, Vol.35, pp. 117-112, 2005.

11) 吉田夏樹, 坂井悦郎, 真下昌章, 大門正機 : 海洋環境下に おける各種セメント硬化体による塩化物イオンの固定化,

Cement Science and Concrete Technology, No.56, pp.400-405, 2002.

12) 竹田博彦, 石田哲也 : 化学結合と電気拘束に基づくセメン 卜硬化体中の塩化物イオン固定化性状, コンクリート工学 年次論文集, Vol.22, No.1，2000.

13) 石田哲也，丸屋 剛, 宮原茂禎 : 異なる鉱物組成ならびに セッコウ量を有するセメント硬化体の塩分平衡特性, コン クリート工学年次論文集, Vol.26, No.1, pp.849-854, 2004.

14) 平尾 宙, 横山 滋: セメント硬化体における塩化物イオン の固定性状，コンクリート工学年次論文集，Vol.23，No.2, pp.1-6, 2001.

15)平尾 宙, Zibara,H., 高橋晴香, 山田一夫 : 塩化物イオンに 及ぼすセメント組成の影響, コンクリート工学年次論文集, Vol.26, No.1, pp.855-860, 2004.

16) Mohammed, T.U., Hamada, H. : Relationship between free chloride and total chloride content in concrete, Cement and Concrete Research, Vol.33, pp. 1487-1490, 2003.

17) $\mathrm{Lu}, \mathrm{X}, \mathrm{Li}, \mathrm{C}$. and Zhang, H.,: Relationship between the free and total chloride diffusivity in concrete, Cement and Concrete Research, Vol.32, pp. 323-326, 2002.

18) 小林一輔 : コンクリートの炭酸化のメカニズム, 土木学会 論文集，No.433/V-15, pp. 1-14, 1991.

19) 佐伯竜彦, 植木 聡, 島 毅 : 塩害と中性化の複合による 塩化物イオンの浸透予測モデルの構築, 土木学会論文集, No.697/V-54,pp. 131-142,2002.

20) 細川佳史, 森 大介, 山田一夫 : 中性化により凝集したセ メント中の内在塩化物イオン濃度と鋼材発錆の関係, 日本 建築学会学術講演梗概集, pp.977-978, 2004.

21) 後藤誠史, 茂 啓次郎, 高木達雄, 大門正機 : セメント硬 化体の細孔径分布とイオンの拡散, セメント技術年報, Vol.36, pp.49-52, 1982.

22) 近藤連一編著:多孔材料一性質と利用一, 第1版4刷, 技報堂 出版, 1986.

23) 前川宏一, 小澤一雅, 國島正彦 : 複数の劣化因子から構成 されるシステムの経時変化予測, コンクリート構造物の寿 命予測と耐久性設計に関するシンポジウム論文集，JCI-C13， pp.39-46, 1988.

24) 佐伯竜彦, 二木 央: 不飽和モルタル中の塩化物イオンの 移動，コンクリート工学年次論文集，Vol.18，No.1，pp.963- 
968, 1996.

25) 日本コンクリート工学協会 : 複合劣化コンクリート構造物 の評価と維持管理計画研究委員会 報告書, 2001 .

26) Barrow, G. M. (藤代亮一訳)：物理化学（第4版），東京化学同 人, 1981.

27) 丸屋 剛, 松岡康訓 : 液相および固相の分析による結合材
の耐久性評価に関する研究，土木学会論文集，No.478/V-21， pp. 41-50, 1993.

28) 島袋 出, 佐々木 崇, 大下英吉 : 中性化による $\mathrm{pH}$ 䙴移が 塩化物イオンの吸脱着性状に及ぼす影響に関する実験的研 究, コンクリート工学年次論文集, Vol.26, No.1, pp.10291034, 2004.

(2005. 4. 26 受付)

\section{INFLUENCE OF CARBONATION ON ADSORPTION ISOTHERM OF CHLORIDE ION IN CONCRETE STRUCTURE UNDER MARINE ENVIRONMENT}

\section{Hitoshi TAKEDA, Eiji OWAKI and Tsuyoshi MARUYA}

Properties of bound chloride ion in concrete are examined for the exsistent structure constructed under a marine environment. The adsorption equilibrium relation varies with higher or lower than the threshold concentration to assume a certain concentration of free chloride ion as a threshold concentration. Moreover, since the chloride adsorption isotherm is changed by carbonation of concrete, the amount of the fixed chloride ion in carbonated concrete decreases and also the amount of the free chloride ion in carbonated concrete increases. 